\title{
Students' Conceptual Change On Human Reproduction Concept Using Scientific Approach
}

\author{
Lathifatuzzahra Taufiq ${ }^{1)}$, S Sriyati, D Priyandonko \\ Biology education of Studies Program, School of Postgraduate Universitas Pendidikan \\ Indonesia, Jl. Dr. Setiabudhi No 229, Bandung 40154, Indonesia \\ Email: azzahra.bunga@gmail.com
}

\begin{abstract}
This study aim was to describe students' conceptual change and investigate the patterns of students' conceptual change in human reproduction system concept through application scientific approach. The research method was weak experimental with one group pretest-post-test design and the number subject of this study were 34 students, $11^{\text {th }}$-grade students of SMAN 1 Indramayu. The instrument was three tier test which given at pretest and post-test. Data analyzed used qualitative and quantitative analysis. Qualitative analysis obtained through analyzed student answer then classified into category suitable. Quantitative analysis obtained through calculation $\mathrm{N}$-gain value and one sample $\mathrm{t}$ test. The results showed mostly students had a misconception and lack of knowledge on all of the human reproduction concept. After a lesson, a conceptual change occurred, a percentage of students who have scientific concept increased from $27,74 \%$ to $79,23 \%$ and the average value of $\mathrm{N}$-gain included into category medium $(0,69)$. According to one sample t test, showed that there was a significant difference between post-test and minimum completeness criteria (KKM) value, 75 (amp. Sign 2 tailed $=0,048$ ). Therefore, a scientific approach supported to build the concept. Furthermore, the analysis also showed students' conceptual change patterns: changed to be positive, changed to be negative, still positive, and still negative. Pattern 4 (lack knowledge to be understanding a concept or changed to be positive) is the most which got $31,69 \%$.
\end{abstract}

Keyword : concepual change, scientific aproach

\section{Introduction}

Students enter in a classroom with preconception which they have formed as result from interaction with their environment around them. Their preconception develops become a more complex concept. But, most of their preconception showed a lack of knowledge (don't know the basis of knowledge) and misconception (contradict with concepts of the experts). Insufficient level of students' cognitive structure, weak reasoning, and weak to an understanding concept as factors misconception source from themselves student. Teachers who teaches concept mistakes make students have misconception too [4]. Book contents which contradict with concept science and use a difficult sentence contribute to students' misconception [3]. Misconception can occur on all concepts, included on human reproduction concept.

Students' misconception or teachers' misconception about human reproduction system identified at contraception concept, structure and function of reproduction organ; fertilization, gestation, and labor; menstruation and gametogenesis [16] [2]. The main 
factor of misconception on human reproduction system comes from their intuition, another word they wrong interpretation the scientific concepts [15] [2]. In term content, human reproduction system concept has a similar characteristic as the other organ system concepts, which consist of several terms and bioprocess which confusing and making it difficult for students to understand [7]. Misconception gives a negative impact on the development of students' understanding because it inhibits the process of building a new scientific concept [11]. Therefore, it should be addressed through a conceptual changing process.

Conceptual change enables students to repair their wrong concepts or increase their previously concepts [5]. Changes conception closely related to the principles of constructivism, because both involve constructing a new concept with its initial conception. Preconceptions students will then be assimilated (adjustment of initial concepts with new symptoms) and accommodation (changing the old concepts into a new concept) to support a change concept. Accommodation occurs when there is dissatisfaction with the existing concepts, new concepts must be intelligible (understandable), plausible (reasonable) and fruitful (can be useful) [15]. The patterns of students' conceptual change identified by pairing students' patterns of preconception and students' patterns of final conception. The pattern of students' conception consists of a pattern of change to be positive, change to be negative, persist positive and persist negative. Ideally, conceptual change can occur through a learning process that leads students to have a better conception.

Using scientific approach can touch cognitive, attitudes, and skill of students. By touching the three realms students will know what, why, and how a knowledge that they got [6]. A scientific approach related with biology learning for pressing the involvement of students in learning, gives students opportunities to build concept independently, familiarize students to formulate, handle the problem, and problem-solving [8]. The procedures of scientific approach appropriate with the scientific process so that students can develops their all potentials to construct knowledge systematically. Students' activities in each stage will make the learning process more meaningful so that conception would be better. The aim of this study was to describe students' conceptual change and investigated the patterns of students' conceptual change on human reproduction system through application scientific approach.

\section{Method}

The research method was weak experimental with one group pretest-post-test design and the number subject of this study were 34 students, $11^{\text {th }}$-grade student of SMAN 1 Indramayu. The sample was taken by a purposive sampling and chosen one group sample. For identifying students' conceptual change and patterns of students' conceptual change used 25 items instrument three-tier diagnostic test which have been validated by experts and validity test. The first tier consists of conventional multiple choice question with one true choice and four distracters. The second tier included 5 reasons (one reason true and four distracters). And the third tier requires students to state how confident they are about their answers for the first and second tier. Three tier 
test classification student into three categories: scientific conception (appropriate with experts' concept or scientific concept), lack of knowledge (don't know the concept), and misconception (contradict with experts' concept) [14].

Steps of analysis procedure were: First, data from pretest and post-test analyzed used qualitative analysis (calculated percentage of students' answer: the number of students who correct answer divided sample x 100\%). The students' answers should classify into some categories which appropriate with their answer pattern (table 1). Quantitively, a significant effect of a scientific approach to students' conceptual change analyzed by statistical one sample t-test and calculation of $n$-gain value.

Table 1. Category of three tier test

\begin{tabular}{|c|c|c|c|c|}
\hline No & Tier 1 & Tier 2 & Tier 3 & Category \\
\hline 1 & True & True & Sure & Understanding (U) \\
\hline 2 & True & True & Not Sure & $\begin{array}{l}\text { Lack of knowledge } \\
\text { (LK) }\end{array}$ \\
\hline 3 & True & False & Sure & Misconception \\
\hline 4 & True & False & Not Sure & $\begin{array}{l}\text { Lack of knowledge } \\
\text { (LK) }\end{array}$ \\
\hline 5 & False & True & Sure & Misconception (M) \\
\hline 6 & False & True & Not Sure & $\begin{array}{l}\text { Lack of knowledge } \\
\text { (LK) }\end{array}$ \\
\hline 7 & False & False & Sure & Misconception (M) \\
\hline 8 & False & False & Not Sure & Misconception (M) \\
\hline
\end{tabular}

Second, to analyze the patterns of students' conceptual change, the patterns of students' responses were analyzed based on students' conceptions partner both on the pretest and post-test. Categories patterns of conception change can be seen in Table 2 below:

Table 2 The Patterns of students' conceptual change

\begin{tabular}{lll}
\hline $\begin{array}{l}\text { Patterns of students' } \\
\text { conceptual change }\end{array}$ & Pair Conception & Description \\
\hline I & U, M & Change negative \\
II & U, LK & Change negative \\
III & U, U & Persist positive \\
IV & LK, U & Change positive \\
V & LK, LK & Persist negative \\
VI & LK, M & Change negative \\
VII & M, U & Change positive \\
VIII & M, LK & Change negative \\
IX & M,M & Persist negative \\
\hline
\end{tabular}

\section{Result And Discussion}


Before learning, students were given a pretest to identified their initial concept. Then, students were learning using scientific approach. Steps of scientific approach appropriate with steps in curriculum 2013. Students did some meaningful activities such as cooperative learning, watching some interactive video, making an illustration of reproduction process, discussion season, etc. After learning, students' final conception was identified by post-test.

\subsection{Students' conceptual change}

According to the analyzed results of the students' pretest answer, mostly student choose a level of confidence not sure, even there were some students who did not answer the question. It showed that preconception majority of students were a lack of knowledge. After the interviews on some students, it was revealed that they did not know concepts although human reproduction system has learned by students in junior high school. The percentage of student who understanding the concept on initial conception was $27,74 \%$ and increased to $79,23 \%$ on final conception. Improved conceptual change showed in the calculation of n-gain in the amount of 0.69 and included into category medium.

Before one sample t-test, normality test should be done. The normality test results showed normal distribution of data requirements $(0,47)$, so one sample t-test can be done. One sample t-test was used to test the significance of the influence of the scientific approach to changing conception. Data post-test compared with KKM biology in school is 75. The results of one sample t-test showed that the p value (Amp. Sign 2 tailed) got 0,048 , that was mean Ho was rejected because the p value (Amp. Sign 2tailed) $<0.05$, the result showed that there was a significant difference between the average value of the post-test and the KKM or in other words the scientific approach influenced to conceptual change.

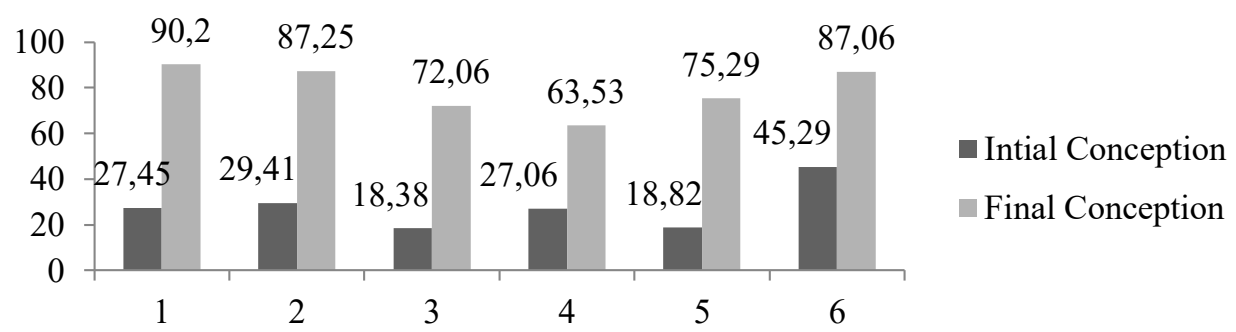

Description: Concept 1 (Structure and function of the male reproductive organ), Concept 2 (Structure and function of the female reproductive organs), Concept 3 (Gametogenesis), Concept 4 (menstrual cycle and ovulation), Concept 5 (Fertilization, gestation, and birth), and concept of 6 (human reproductive system disorders)

Figure 1. Initial Concept and Final Concept on Each Human Reproductive System Concepts Learning Through Scientific Approach

According to Figure 1, showed that students' percentage who answer appropriate with the scientific concept increased at all of concepts It was indicated a conceptual change. The concept of human reproductive system disorders got the highest percentage of students' scientific conception on initial concept that was equal to $45.29 \%$ and the 
lowest percentage was gametogenesis concept that was $18.38 \%$. At the final concept, the concept of the structure and function of the male reproductive organs got a highest percentage of students scientific conception that was equal to $90.2 \%$ and the lowest percentage occurred in the menstrual cycle and ovulation concept that was equal to $63.53 \%$ The number gain of students scientific conception at every concept was not same, because each concept has a different level of complexity, different the difficulty level, and a different level of convenience. Similar explained by Oztas [13] that misconceptions often occurred on the concept that has a high complexity.

3.1.1. Structure and function of the male reproductive organ. At the concept of structure and function of male reproductive organ was only about $27.45 \%$ had initial conception in appropriate with the scientific concept. 36.27\% lack of knowledge, and $36.27 \%$ had misconception. Students' misconceptions related to the assumption that testes and vas deferens organ role as stabilizer male reproductive system on the extreme temperatures; termination of the vas deferens will make stops sperm production and maturation of sperm impaired; the smooth muscle of the scrotums contract in hot and cold temperatures. After the lesson ended, the students who have scientific conception increased to $90.20 \%$ it means, understanding concepts about structure and function of the male reproductive organ to be better for most students.

3.1.2. Structure and function of the female reproductive organ. At the concept of structure and function of the female reproductive organs, only $29.41 \%$ had initial conception in appropriate with the scientific concept. Students assumed the ovaries become place of fertilization because fertilization occurs after the ovum was formed; ovary and oviduct become a place to fetus grow and develop. After lesson, the percentage of students' scientific conception increased to $87.25 \%$. Students have understood if ovaries were the place of oogenesis, oviduct or fallopian tube was the place of fertilization and uterus which thick-walled and rich in blood was the place of a fetus to grow and develop.

\subsubsection{Gametogenesis concept}

Gametogenesis concept was a concept that had the lowest percentage of students who had a scientific concept in the amount of $18.38 \%$. At this concept, the students' initial conceptions dominated by students' lack of knowledge conception of $59.56 \%$. While $21.32 \%$ were misconceptions. One of the misconceptions that students assumed if oosit and spermatogonium were haploid because of a result of mitotic which chromosome not reduction. After a lesson, students who had scientific concept increased to 72,06\%. But, the percentage of misconception also increased. According to analyzed the post-test students' answer, most of the misconception occurred on oogenesis sub conception. Mostly student mistakes showed ootid on oogenesis scheme, some students showed to the polar body as ootid.

\subsubsection{Menstrual cycle and ovulation concept}

Students' initial conception at the menstrual cycle and ovulation concept showed the percentage of scientific concept was 27,06\%. Most of the students' misconception related to error determining the period of menstruation and ovulation. Students thought 
that the beginning of menstruation period is calculated from the last day of the menstrual period the previous month when the endometrium is gradually thickened. Students also assumed that ovulation occurs when the corpus luteum destroyed. After the lesson, the students' appropriate scientific conception increased to $63.53 \%$. Although increased, this concept had the lowest percentage of students' scientific conception and had the highest misconception 30,59\%. It was same with Chainarosi [2] who found the highest misconceptions at the concept of the menstrual cycle and ovulation.

\subsubsection{Fertilization, gestation, and labor}

On the initial conception, students who had scientific conception at $18,82 \%$ and increased to $75,29 \%$ on final conception. One of conceptual change at this concept, change the students' assumption about a process of zygote formation occurs at uterus into zygote formed at the fallopian tube after fertilization process. But, at this concept was also found students' misconception on final conception. For example, students assumed that characteristic of gastrulation stage embryos that was shaped like a hollow ball containing fluid.

\subsubsection{Human reproduction system disorders}

Students have had a scientific conception on initial conception at $45,29 \%$ and more increased after a lesson. But, misconceptions were also found on final conception. For example, they assumed that shape of sperm will be abnormal if there is disorder at prostate gland. The correct answer is a disorder of the prostate should cause sperm becomes resistant to the situation of women's reproductive acid because the prostate gland produces alkaline liquid.

\subsection{The patterns of students' conceptual change}

The patterns of students' conceptual change on human reproduction system listed in the table. The pattern IV was highest percentage which got average 31,69\% and lowest percentage was pattern VII which got $0,47 \%$. Based on that, showed that student tended changed concept from lack of knowledge on initial concept to scientific conception on final conception or other words changed to positive. The scientific approach provides an opportunity for students to construct concepts through various activities and not just be accepted information from teacher [1]. Summary of the students' conceptual change patterns on each concept can be seen in Table 4.

Table 4. Recapitulation of the students' conceptual change patterns on human reproduction system

\begin{tabular}{llllllllllll}
\hline \multirow{2}{*}{ No } & Concept & \multicolumn{1}{c}{ Patterns of students' conceptual change } & & & \\
& I & II & III & IV & V & VI & VII & VIII & IX \\
\hline \multirow{2}{*}{1} & $\begin{array}{l}\text { Structure and } \\
\text { function of the } \\
\text { male reproductive } \\
\text { organ }\end{array}$ & 0.98 & 0.00 & 26.47 & 35.29 & 0.98 & 1.96 & 29.41 & 0.00 & 4.90 \\
& & & & & & & & &
\end{tabular}




\begin{tabular}{llllllllllll}
\hline \multirow{2}{*}{ No } & Concept & \multicolumn{1}{c}{ Patterns of students' conceptual change } & & & \\
& I & II & III & IV & V & VI & VII & VIII & IX \\
\hline 2 & $\begin{array}{l}\text { Structure and } \\
\text { function of the } \\
\text { female }\end{array}$ & 0.56 & 0.00 & 27.73 & 32.77 & 1.40 & 3.22 & 28.99 & 0.84 & 4.48 \\
$\begin{array}{l}\text { reproductive organ } \\
3\end{array}$ & 1.47 & 1.47 & 15.44 & 40.44 & 4.41 & 15.44 & 16.91 & 0 & 4.41 \\
$\begin{array}{l}\text { Gametogenesis } \\
\text { Menstrual cycle } \\
\text { and ovulation }\end{array}$ & 5.88 & 1.18 & 19.41 & 22.94 & 3.53 & 14.12 & 22.35 & 1.18 & 9.41 \\
& $\begin{array}{l}\text { Fertilization, } \\
\text { gestation, and }\end{array}$ & 2.33 & 0.60 & 20.74 & 32.19 & 2.76 & 10.52 & 23.92 & 0.82 & 6.11 \\
$\begin{array}{l}\text { labor } \\
\text { Human } \\
\text { reproductive } \\
\text { system disorders }\end{array}$ & 2.35 & 0 & 43.53 & 26.47 & 1.18 & 1.76 & 17.06 & 0 & 7.65 \\
\hline Average & 2.26 & 0.54 & 25.55 & $\mathbf{3 1 . 6 9}$ & 2.38 & 7.84 & 23.11 & 0.47 & 6.16 \\
\hline
\end{tabular}

3.2.1. The Pattern I: Changed negative (U, M). Based on table 4, showed that conception which has the highest pattern I was menstrual cycle and ovulation, got $5,88 \%$, and structure function of female organ reproduction system got $0,56 \%$ and be a concept which got the lowest percentage. On this pattern, occurred conceptual change negatively. Students' scientific conception changed to misconception. Muchyar [9] explained that learning process in a classroom, students' experiences that happened, and students' social environment potentially leading to students' misconceptions.

3.2.2. Pattern II: Changed negative ( $U, L K$ ). Based on table 4 showed that concept which had a highest pattern II was gametogenesis conception, got 1,47\%, while concept which had the lowest percentage was on the three concepts, structure and function of male reproductive organ system, structure and function of female reproductive organ system, and human reproduction system disorders who got $0 \%$. Pattern II was changed conception to negative. Students' conceptions which appropriate with science concept change to lack of knowledge. That was mean, after a learning, students become more confused even hesitate with their concept.

3.2.3. Pattern III: Persisted positive $(U, U)$. Pattern III was persist positive, scientific conception on before learning remained a scientific conception as well as learning. Based on table 4, concept which has a highest percentage of pattern III was human reproduction system disorders concept, got $43,53 \%$, while concept which had a lowest percentage was gametogenesis, got $15,4 \%$. The concept of the human reproductive system disorders concept have taught in previous education level and was closely related to the daily life of students, it was reasonable if the student already has a scientific conception of prior knowledge and tend to hold the conception after learning.

3.2.4. Pattern IV: Changed positive (LK, U). Based on table 4, a concept which had the highest percentage of pattern IV was gametogenesis concept, got 40,44\%, while concept which has a lowest percentage was a menstrual cycle and ovulation concept got $22,94 \%$. In pattern IV, students had a lack of knowledge conception on initial concept and change to scientific conception. The conceptual change that happened leads to expansion of the concept, can complete students' initial concept. Through scientific 
approach procedure, such as observation, asking a question, exploration to got information, association their information, and discuss at the communication their information, helped students to expansion their conception.

3.2.5. Pattern V: Persisted negative ( $L K, L K$ ). Pattern $\mathrm{V}$ was persisted negative. Into category lack of knowledge on initial conceptions persisted until the lesson ended. Based on Table 4 concept that the highest percentages of pattern IV was gametogenesis that was $4.41 \%$ while the concept had the lowest percentage was the structure and function of the male reproductive system, $0.98 \%$.

3.2.6. Pattern VI: Changed negative (LK, M). In pattern VI, students' initial conception into category lack of knowledge and after lesson students had a conception, but contradicted with a scientific concept or called misconception. Based on Table 4 the highest percentage found at gametogenesis concept that was $15.44 \%$, while the lowest percentage found at the concept of the human reproductive system disorders in the amount of $1.76 \%$. It can be influenced by differences in the characteristics of the concept. Gametogenesis was stranger concept, abstract, and need more visualization skill than human reproduction disorders concept. The content material that has a level of complexity higher than other content more chances cause misconceptions [13]

3.2.7. Pattern VII: Changed positive $(M, U)$. Based on Table 4 the highest percentage found at the concept of the structure and function of the male reproductive system, $29.41 \%$, while the lowest percentage contained at gametogenesis concept, $16.91 \%$. Pattern conception VII was a conceptual change that leads to repaired misconception on initial conception to scientific conception on final conception. The conceptual change stimulated by dissatisfaction of students' initial concept. This situation enhance students should changed their initial concept.

3.2.8. Pattern VIII: Changed negative (M, LK). In Pattern VIII, a misconception on initial concept changed to lack of knowledge on final conception or changed to negative. Based on Table 4 the highest percentage found at the concept of the menstrual cycle and ovulation cycle, $1.18 \%$, while the lowest percentage contained at the concept of the structure and function of the male reproductive organ, gametogenesis and the human reproductive system abnormalities in the amount of $0 \%$.

3.2.9. Pattern IX: Persisted negative ( $M, M)$. Pattern IX was persisted negative. On initial and final conception persisted misconception. Based on Table 4 the highest percentage found at the menstrual cycle and ovulation concept, $9.41 \%$, while the lowest percentage found at gametogenesis concept, $41 \%$. This pattern proved if misconception blocking to build a new scientific concept that misconception inhibits the process of formation of new concepts right. Misconception holds the process of formation new right concepts [11]. And misconception long lasting and resistant to corrected [12].

Based on the analysis, the gain and patterns of students' conceptual change in every student were different because students have special characteristics that cannot be equated with other students. Each student has needs, interests, intellectual level, ability, and the question that will never be equated. Conceptual change influenced by students' cognitive factor, students' affective factor, and students' social factor [17]. If student 
has a high ability in cognitive, affective, and social factor, they would have a good conception. Furthermore, conceptual change influenced by students' initial conception or called students' preconception. Students who have a scientific concept on initial conception would be easier to build a new scientific concept.

The scientific approach learning on human reproductive system has a role in students' conceptual change. Several reasons scientific approach can facilitate conceptual change were, first, the scientific approach positioned students as the centre of learning (student centre). Student learning centre gives opportunities student to construct their knowledge through a various activities so that they will gain a deep understanding and can improve the quality of students. Conceptual change occurred through effective instructional activities and student centre [9].

Second, the scientific approach had a stage which full of a scientific method (observation, questioning, explore information, association information, communication), involving many of sensory system, and create students' meaningful learning experiences. Observed was able to bring curiosity of students that will raise questions. Propose activities will encourage students to engage in searching for information. Student explores information by various ways, source, and the system senses that they have. Their information then associated with the activities of reasoning. Students will match the information they received with the phenomena as well as with other theories. Furthermore, through the activities of communicating, students can sharpen verbal ability and gained a lot of additional information to complements and repair their information. This characteristic is most likely to lead students to a better understanding of the concept. Marjan [7] who obtained results that students' learning outcomes increased after learned using a scientific approach.

Third, the scientific approach enhances students work team in small groups and enables discussion process. In the discussion, the teacher will give clarification and strengthening of the knowledge which has been built by students. Work team and discussion helpful to building a better knowledge on students. Through exchange opinion, students can obtain additional knowledge from others opinions which different with students' opinion. Students can also find out where the mistakes of its concepts so will be helped transform for the better conception.

\section{Conclusion}

The study findings that the scientific approach influence students' conceptual change on human reproduction system. In more detail can be described as follows: (1) percentage of students who have scientific concept increased from 27, 74\% at before learning to 79 , $23 \%$ after learning using scientific approach (2) All concepts of human reproduction concept occurred conceptual change with different gain value (3) pattern IV got a highest percentage, it means that mostly student change their conception from lack knowledge to understanding concept. For enhance the conceptual change, activities in scientific approach designed customized with characteristic of contents and students. 


\section{Acknowledgments}

Researcher says many thanks to the supervisors Dr.Hj. Siti Sriyati, M.Si. and Dr. Didik Priyandoko, M.Si. which has helped researchers from planning a research proposal to prepare research as well as the writing of this article. Researchers are also very grateful to Mrs. Dessilia Senja and all participants who have been willing to be a part of this study.

\section{References}

[1] Asikin N, Irawati M H \& Syamsuri 2016 J. Pedagogi Hayati Pembelajaran Biologi Berpendekatan Saintifik Model Sains Teknologi Masyarakat Untuk Meningkatkan Hasil Belajar Siswa 01 1-10

[2] Chaniarosi F L 2014 Jurnal EduBio Tropika Identifikasi Miskonsepsi Guru Biologi SMA Kelas XI IPA Pada Konsep Sistem Reproduksi Manusia 0202 $187-250$

[3] Dwi I V 2013 Jurnal Pendidikan Sains E-Penra Penerapan Pendekatan Contextual Teaching And Learning (Ctl) Untuk Mengatasi Miskonsepsi Siswa Pada Materi Fotosintesis 0102 21-29

[4] Genc M 2013 International Journal On New Trends In Education And Their Implications Prospective Elementary Teachers Misconceptions In Biology Lesson: Urinary System Sample 43 1309- 6249

[5] Hewson, Peter 1992 Research And Curriculum Development In Science Technology Conceptual Change In Science Teaching And Teacher Education.

[6] Hosnan 2014 Pendekatan Saintifik Dan Kontekstual Dalam Pembelajaran Abad 21 Ghalia Indonesia: Jakarta

[7] Kurniadi, Widodo, Rochintaniawati \& Riandi 2015 Prosiding Simposium Nasional Inovasi Dan Pembelajaran Sains 2015 Analisis Reasoning Skill siswa Pada Pembelajaran Biologi SMA

[8] Marjan J 2014 e-Journal Program Pascasarjana Universitas Pendidikan Ganesha Program Studi IPA Pengaruh Pembelajaran Pendekatan Saintifik Terhadap Hasil Belajar Biologi dan Keterampilan Proses Sains Siswa MA Mu'alimat NW PAncor Selong Kabupaten Lombok Timur 4

[9] Muchyar, Widodo \& Riandi 2014 Jurnal Pengajaran MIPA Profil Perubahan Konseptual Siswa Pada Materi Kependudukan dan Pencemaran Lingkungan 20 $165-75$

[10] Naz \& Nasreen 2013 Ankara University, Journal Of Faculty Of Educational Science An Exploration Of Students Misconceptions About The Concepts Classification Of Animals At Secondary Level And Effectiveness Of Inquiry Method For Conceptual Change 462 195-214.

[11] Ozcan, Yildrim, Ozgur 2012 Procedia Social And Behavioral Sciences Determining Of The University Freshmen Students' Misconceptions And Alternative Conceptions About Mitosis And Meiosis 46 367-3680.

[12] Ozgur 2013 International Journal Of Environmental \& Science Education The 
Persistence Of Misconceptions About The Human Blood Circulatory System Among Students In Differents Grade Levels 82 255-268.

[13] Oztas F 2014 Procedia Social and Behavioral Sciences How do high school students know diffusion and osmosis? High school students difficulties in understanding diffusion \& osmosis 166 3679-3682

[14] Pesman \& Eryilmaz 2010 The Journal of Education Research Development of a Three Tier Test to Asses Misconception About Simple Electric Circuit

[15] Posner J G 1982 Science Education Accomodation Of A Scientific Conception: Towards A Theory Of Conceptual Change $662221-227$

[16] Ramdhani R \& Hasanudin 2016 Jurnal Ilmiah Mahasiswa Pendidikan Biologi Identifikasi Miskonsepsi Siswa Pada Konsep Sistem Reproduksi Manusia Kelas XI IPA SMA Unggul Ali Hasjmy Kabupaten Aceh Besar 1 1 1-9

[17] Suparno P 2013 Miskonsepsi Dan Perubahan Konsep Dalam Pendidikan Fisika. Jakarta 